\title{
Stock price reaction to cash dividend announcements in Vietnam
}

\author{
NGUYEN XUAN TRUONG \\ Hanoi University - truongnx@hanu.edu.vn \\ DAO MAI HUONG \\ Hanoi University - huongmaidao.1tu@gmail.com \\ NGUYEN THI VAN ANH \\ Hanoi University - ntva1279@gmail.com
}

\begin{abstract}
ARTICLE INFO
ABSTRACT

Article history:

Received:

Sep. 17, 2015

Received in revised form:

Sep. 16, 2016

Accepted:

Mar. 31, 2017

Keywords:

Dividend announcement

Price reaction

Event study

This study attempts to investigate the stock price reaction to dividend announcements using data of Vietnamese listed firms on Hochiminh Stock Exchange (HOSE). Standard event study methodology has been employed on a sample of 198 cash dividend announcements made in 2011. The results show that stock prices react significantly and positively to the announcements of cash dividends, including both dividend increasing and dividend decreasing events. It is also plausible that cumulative abnormal returns exhibit an increasing trend before announcement yet a decreasing trend after announcement dates. More specifically, we find positively significant cumulative abnormal returns of around $1.03 \%$ on announcement dates; other larger windows also demonstrate positive abnormal returns of around $1.3 \%$. In addition, cash dividends have different effects on share prices of firms from different industries. These results support the signaling hypothesis and are also consistent with prior findings of empirical research done on more developed markets, i.e. the US and the UK.
\end{abstract}




\section{Introduction}

Numerous studies have been conducted in the area of market reaction to dividend announcements in many developed markets such as the US, the UK, and Australia. Researchers found evidence to support the hypothesis that dividend announcement

s do convey information on the future prospects of firms (e.g., Miller \& Rock, 1985; Easton, 1991). It was claimed that the dividend announcements would signal managers' expectation of future earnings of the firm, and therefore contain the information to which shareholders will react. As a result, stock prices would be affected.

However, little evidence has been found to support this theory by using data from less developed markets such as Vietnam. The Vietnamese stock market is characterized by low information transparency, which might be a reason for the potential information leakage surrounding cash dividend announcements. This paper is our first attempt to examine the information content and signaling effect of dividend announcements on the Vietnam's stock market. For this purpose, the research, using data of Vietnamese listed firms on HOSE in 2011, is conducted to answer the following questions: (i) in which direction have stock prices reacted to dividend announcements?; (ii) how large has the change in stock prices been recorded compared to the amount of cash dividends?; (iii) is there any difference in stock price reaction to the announcement of dividends of one industry to another?; (iv) does the market react differently to dividend increase and dividend decrease announcements?; and (v) do dividend yields provide explanation for the change in stock abnormal returns during a dividend announcement period?

The outline of the paper is as follows. Section 2 begins with the review of relevant theoretical frameworks in the field of dividend and dividend signaling effect. In section 3, we present event study methodology as well as data collection and processing steps. Section 4 examines the results from our study and provides a thorough discussion on the findings. Section 5 concludes the paper.

\section{Theoretical framework}

The questions of whether a company should pay dividend and how dividend policies affect the firm's performance remain controversial over decades. Basically, there are two major opposing schools of thought - one supporting the idea of dividend irrelevance and the other arguing for the relevance of dividend on firm value. An important contribution to the first view is dividend irrelevant theory developed by Miller and Modigliani (M\&M) (1961). This theory indicates that there is no effect of dividends on a company's capital structure or stock price under perfect capital markets with information asymmetries and the absence of taxes and transaction costs. The firm's value is dependent on its earnings, which is the result of its investment policies. These authors further stated that investors are indifferent between capital gain and dividend payment, and therefore base their investment decision on the future earnings of the firm regardless of its dividend policies. Another study by Black and Scholes (1974) 
found no significant relationship between dividends and stock prices, arguing for the irrelevance of dividend policies. In their study neither high-yield nor low-yield dividend payout influences stock prices. Others, such as Miller and Scholes (1978), Hess (1981), and Bernstein (1996), provided evidence in line with the dividend irrelevance theory.

In contrast, Lintner (1962) and Gordon (1963) independently conducted their research indicating that dividends are relevant to determining the value of the firm. Both Lintner (1962) and Gordon (1963) argued that investors in valuing stocks prefer dividends as they are more certain than future capital gain, which might or might not be realized. Therefore, the higher payouts result in lower costs of capital and hence higher stock prices. This school of thought is commonly known as the Bird-in-the-hand theory as derived from the old saying that "a bird in the hand is worth two in the bush." In support of dividend relevance hypothesis, Walter's (1963) model demonstrated a significant relation between internal rate of return and cost of capital that are of crucial importance in determining optimal dividend policy for maximizing shareholders' wealth. Another hypothesis, namely Tax preference theory, accounts for the different tax treatment between dividends and capital gains. This theory is more realistic than that of M\&M with the assumption of a perfect capital market where any possible tax effect is excluded. According to the tax preference hypothesis, low payout ratios lower the cost of capital, thereby increasing stock prices.

In another counteraction with the M\&M dividend irrelevance theory, the signaling effect hypothesis considers the existence of asymmetric information between insiders (managers and directors) and outsiders (shareholders). Otherwise, M\&M assumes that managers and investors have equal and free access to the same information. In the real world, managers should possess information on the current performance and future prospects of the firm, which is not available to investors. This informational gap will cause difficulties for investors to accurately measure the intrinsic value of the firm. Due to the lack of complete and accurate information available to shareholders, managers' decisions usually send some signals to the market. In this way dividend announcements may convey some implicit information on the firm's potential future earnings in terms of both the stability of, and changes in, dividends (Al-Malkawi et al., 2010). An increase in dividend payout can be indicative of the firm's having good profitability and potentially high future earnings, and hence the share prices can react favorably. Conversely, a dividend cut could be interpreted as the firm's poor future prospects; therefore, share prices may decrease. As a result, managers are often cautious with the decision to raise dividends as they must believe that the firm's earnings should be permanently sustainable.

Numerous empirical studies using quantitative and qualitative approaches have confirmed the relevance of the dividend on firm value. For example, studies conducted by Asquith and Mullins (1983) and Miller and Rock (1985) show that dividend increases result in positive abnormal returns in share 
prices. Additionally, some found evidence to support the signaling effect hypothesis. For instance, Nissim and Ziv (2001), who used a particular model of earnings expectations applied to the firms listed on the New York Stock Exchange (NYSE), the US, found positive correlation between dividend changes and future earnings in two subsequent years after the dividend change. Other studies carried out in different non-US markets, such as the UK (Lonie et al., 1996; Gunasekarage \& Power, 2006), Australia (Easton, 1991), and Japan (Harada \& Nguyen, 2005) also provided empirical evidence of the informational content hypothesis and the dividend effect on share prices. In addition, a few studies have initiated in emerging markets, such as Malaysia (Hashemijoo et al., 2012; Lee et al., 2012) and Thailand (Suwanna, 2012).

One step further beyond the examination of the dividend relevance hypothesis, the price reaction to dividend announcements on ex-dividend dates is of interest to many financial researchers. Eades et al. (1984) pointed out that there is an increase in stock prices before ex-dividend dates and conversely a stock price decrease after these dates. This view was confirmed by Lakonishok and Vermaelen (1986). Another empirical study conducted by Boyd and Jagannathan (1994) further discovered that a marginal price drop is not significantly different from a dividend amount after the exdividend date, providing evidence for the rule of thumb of one-for-one price drop adopted over the past decades.

\section{Research design}

\subsection{Data collection and sample con- struction}

The initial sample includes 352 cash dividend announcements of stocks on HOSE in 2011. The following criteria have been used for inclusion in our final sample: (i) stock must have been traded for at least one year prior to the announcement date; (ii) all "financial stocks" and funds are excluded; (iii) there are no other corporate significant events such as stock dividends, stock splits, and stock repurchases around the announcement dates of cash dividends; and (iv) cash dividend announcements must comprise several related features such as ex-dividend date, record date, and payment dates.

The resulting sample includes 198 cash dividends, of which 61 cash dividends are made by firms from Basic Materials sector, 62 from Industrials sector, and 32 from Consumer Goods sector. The highest dividend level seems to have been paid by utilities firms, followed by Industrials firms, while those from Oil \& Gas industry sector seem to pay the lowest dividend level. 


\section{Table 1}

Descriptive statistic of sample firms

\begin{tabular}{lcccc}
\hline Industry sectors & $\begin{array}{c}\text { Numbers of } \\
\text { cash dividend }\end{array}$ & $\begin{array}{c}\text { Average amount } \\
\text { ('000 VND) }\end{array}$ & $\begin{array}{c}\text { Average stock price } \\
\text { ('000 VND) }\end{array}$ & $\begin{array}{c}\text { Average yield } \\
\text { (\%) }\end{array}$ \\
\hline Basic Materials & 32 & 1.23 & 23.83 & 7.35 \\
Consumer Goods & 61 & 1.17 & 18.56 & 8.57 \\
Consumer Services & 11 & 0.99 & 17.29 & 9.84 \\
Health Care & 9 & 1.67 & 25.42 & 10.97 \\
Industrials & 62 & 1.17 & 12.97 & 12.81 \\
Oil \& Gas & 2 & 1.30 & 30.46 & 4.44 \\
Technology & 8 & 1.28 & 19.55 & 10.86 \\
Utilities & 13 & 1.30 & 11.74 & 15.20 \\
Total & 198 & 1.21 & 17.67 & 10.37 \\
\hline
\end{tabular}

\subsection{Event study methodology}

This study employs the standard event study methodology proposed by Brown and Warner (1985) to assess the impact of dividend announcements on stock prices. The examination period is set 261 days to 61 days prior to the announcement date. Event windows are set at -10 days to +10 days during event dates, which might help to mitigate any possible information leakage before the official announcement date. Day 0 is defined as the announcement date of the events.

It is required to compute the abnormal return (or excess return), which is "the actual ex-post return of the security over the event window minus the normal return of the firm over the event window" (MacKinlay, 1997). The following formula is used to estimate abnormal returns:

$$
A b_{j t}=R_{j t}-E\left(R_{j t}\right)
$$

where:

Abjt: abnormal return of event $j$ on day $t$

Rjt: ex-post return of event $\mathrm{j}$ on day $\mathrm{t}$

$E(R j t)$ : ex-ante return of event $j$ on day $t$

Often, researchers opt to select mean adjusted return and/or market model to find the expected returns for securities. However, Market Model has been chosen for this study to identify expected returns for several reasons: Brown and Warner (1985) argued that the use of market model is itself sufficient and well specified under variety of conditions; this method has been widely employed in the studies of corporate events such as corporate spin-offs and dividends (e.g., Brown and Warner, 1983; Krishnaswami and Subramaniam, 1999; Syeda and Nousheen, 2008). 
For each share, we calculate expected return for event day $\mathrm{t}$ as follows:

$$
R_{j t}=\alpha_{i}+\beta_{j t} R_{m t}+\varepsilon_{j t}
$$

where:

Rjt: observed return for security $\mathrm{j}$ on day t

ajt: constant term

$\beta \mathrm{jt}$ : beta coefficient of security $\mathrm{j}$ on day $\mathrm{t}$

$\mathrm{Rmt}$ : observed return on the market on day $\mathrm{t}$

عit: error term

By rearranging Equation (2), abnormal returns can be estimated:

$$
\varepsilon_{j t}=R_{j t}-\left(\alpha_{i}+\beta_{j t} R_{m t}\right)
$$

The consensus proxy for the market return used in Vietnam is the VNINDEX. Estimators $\alpha j$ and $\beta j$ (i.e. model parameters) are calculated using an estimation period commencing 261 days before the announcement date and ending 61 days before the announcement date.

Daily abnormal returns (ARt) for each security with respect to specific time interval are summed over to obtain the following:

$$
A R_{j, t}=\sum_{t=-1}^{1} \varepsilon_{j t}
$$

Then, we derive average cumulative abnormal return (CAR) by taking arithmetic mean of the summation from Equation (5) across all observations in the sample. CAR represents the aggregate price reactions of the firms in the sample over the selected event window. For example, CAR for the event window day -1 to day +1 is calculated using the following equation:

$$
C A R_{j, t}=\frac{1}{N} \sum_{j=1}^{1} A R_{j, t}
$$

where ARt denotes summation of daily abnormal return for each security during 3 days.

In accordance with the use of market model, we propose standardized residual test for the significance of the result. The method was first introduced by Patell (1976) and adopted by Brown and Warner (1985). The advantage of this technique is that it helps reduce type I error of rejecting a null hypothesis (e.g., mean abnormal returns are zero). The error could happen if there are substantial increases in the variance of share returns around the announcement date. To induce type I error and allow for out-of-sample estimation error, it is necessary to standardize the abnormal returns. In this instance, abnormal returns will be divided by the standard error of the market model. The formula is as follows:

$$
S R_{j, t}=\frac{A R_{j, t}}{S\left(\varepsilon_{j, t}\right)}
$$

where:

$A R_{j t}$ : summation of daily abnormal return of security $\mathrm{j}$ during a period

$S\left(\varepsilon_{j t}\right)$ : standard error of abnormal returns estimated from market model

Subsequently, the test statistics ( $\mathrm{Nt}$ denotes the number of sample securities at day $\mathrm{t}$; Tstat will be distributed unit normal for a large number of sample securities).

$$
T_{\text {stat }}=\sum_{j=1}^{N_{t}} S R_{j, t} *\left(N_{t}\right)^{-1}
$$

In comparing abnormal returns of subsamples, t-test is applied to identify if each sub-sample's mean differs significantly. This is possible under a two-sample t-test assuming unequal variance. The sub-sample 
comparisons for which t-test is applied include: (i) Basic Materials; (ii) Consumer Goods; and (iii) Industrials.

Additionally, the event study methodology has been used to access level of abnormal returns following dividend announcements, multivariate models have been built to explore the nexus between size of dividends and price reactions.

\section{Results and discussion}

This section is divided into four parts. The first presents the results of abnormal stock returns of the overall data, covering all cash dividend announcements on HOSE in 2011. The second shows the results of three sub-samples categorized by three dominant industries, namely Industrials, Consumer Goods, and Basic Materials. Next, we discuss dividend change, i.e. dividend increase and dividend decrease announcements. Finally, the regression analysis results are illustrated of the relationship between dividend yields and stock price reactions.

\subsection{Whole sample results}

Notably, CARs show an increasing pattern before the announcement dates and start to decline three days after these dates. This pattern supports the general signaling hypothesis that dividend conveys positive signal to the market. Positive abnormal stock returns are then absorbed when ex-dividend dates approach. The average distance between the announcement dates and ex-dividend dates is 10 business days. In addition, it is evident that there exists the information leakage of cash dividend before the official announcement dates (i.e. the market reacts strongly and significantly 03 days prior to the events).

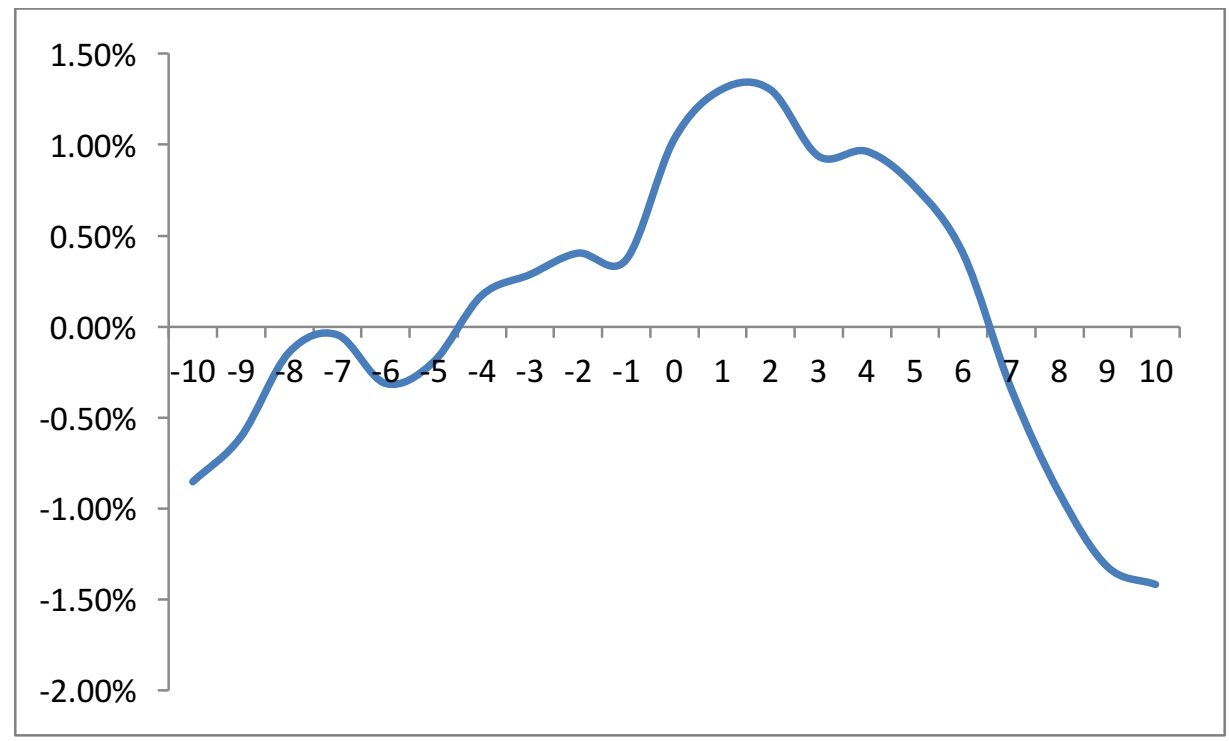

Figure 1. CARs of the whole sample 
Specifically, the results demonstrate strongly and significantly positive abnormal stock returns of $1.03 \%$ on the day of announcement. CARs reached a peak at $1.3 \%$ for the two windows, i.e. +1 day and +2 days after the announcement dates. Their test statistics are also at the highest significant levels. For the larger windows such as Day +6 to Day 0, significantly positive abnormal stock returns are shown. Table 2 presents the CARs of all windows and their significance levels (note that two windows-Day -3 to Day 0 and Day -5 to Day 0 - are not statistically significant at $10 \%$ ). This result is consistent with the finding of Gupta et al. (2012).

\section{Table 2}

CARs of the whole sample

\begin{tabular}{|c|c|c|}
\hline Days & CARs & SRT \\
\hline-10 & $-0.85 \%$ & $-11.58 * * *$ \\
\hline-9 & $-0.61 \%$ & $-8.36 * * *$ \\
\hline-8 & $-0.14 \%$ & $-2.58 * * *$ \\
\hline-7 & $-0.05 \%$ & -1.26 \\
\hline-6 & $-0.31 \%$ & $-4.33 * * *$ \\
\hline-5 & $-0.20 \%$ & $-2.57 * *$ \\
\hline-4 & $0.17 \%$ & 1.27 \\
\hline-3 & $0.28 \%$ & $2.93 * * *$ \\
\hline-2 & $0.40 \%$ & $4.12 * * *$ \\
\hline-1 & $0.37 \%$ & $3.84 * * *$ \\
\hline 0 & $1.03 \%$ & $11.71 * * *$ \\
\hline 1 & $1.30 \%$ & $15.42 * * *$ \\
\hline 2 & $1.30 \%$ & $15.01 * * *$ \\
\hline 3 & $0.94 \%$ & $11.17 * * *$ \\
\hline 4 & $0.96 \%$ & $12.00 * * *$ \\
\hline 5 & $0.77 \%$ & $9.91 * * *$ \\
\hline 6 & $0.40 \%$ & $6.02 * * *$ \\
\hline 7 & $-0.34 \%$ & $-2.37 * *$ \\
\hline 8 & $-0.92 \%$ & $-8.28 * * *$ \\
\hline 9 & $-1.32 \%$ & $-13.72 * * *$ \\
\hline
\end{tabular}




\begin{tabular}{ccc}
\hline Days & CARs & SRT \\
\hline 10 & $-1.42 \%$ & $-15.02 * * *$ \\
\hline
\end{tabular}

Note: $* * *, * *$, and $*$ denote significance of $1 \%, 5 \%$, and $10 \%$ respectively.

We also perform paired t-test to check the difference between CARs of post-announcements and pre-announcement effects. The results are shown in Table 3 below.

\section{Table 3}

Results of t-test for difference CARs of pre- vs. post-announcements

\begin{tabular}{llcc}
\hline $\mathrm{N}=198$ & Mean & Test statistics & Significance \\
\hline Pre-Announcement & & & \\
Day -3 to Day 0 & $0.17 \%$ & & \\
Day -2 to Day 0 & $0.28 \%$ & & \\
Day -1 to Day 0 & $0.40 \%$ & & \\
Post-Announcement & & 2.45 & $5 \%$ \\
Day +3 to Day 0 & $1.30 \%$ & 2.85 & $1 \%$ \\
Day +2 to Day 0 & $1.30 \%$ & 2.63 & $1 \%$ \\
Day +1 to Day 0 & $1.03 \%$ & & \\
\hline
\end{tabular}

The test results illustrate that there is a statistically significant difference between CARs of pre-announcement and post-announcement dates for the three event windows. Accordingly, though stocks react positively to cash dividend announcements, there is a stronger effect reported for postannouncement dates than that of pre-announcement dates.

\subsection{Results by industry sectors}

Out of 198 announcements in our sample, 32 were made by firms from Basic Materials industry sector, 61 from Consumer Goods industry sector, and 62 from Industrials industry sector. We anticipate that the effect of cash dividend announcements is different among industries. The results of subsample CARs are presented in Table 4. 


\section{Table 4}

Sub-Sample CARs

\begin{tabular}{|c|c|c|c|c|c|c|c|}
\hline \multicolumn{3}{|c|}{ Sub-Sample CARs } & \multirow[b]{2}{*}{$\begin{array}{l}\text { Con- } \\
\text { sumer } \\
\text { Goods }\end{array}$} & \multirow[b]{2}{*}{ Industrials } & \multicolumn{3}{|c|}{ t-test } \\
\hline $\begin{array}{l}\text { Windows } \\
\text { (day) }\end{array}$ & Statistics & $\begin{array}{c}\text { Basic } \\
\text { Materials }\end{array}$ & & & $\begin{array}{c}\text { Basic vs. } \\
\text { Con- } \\
\text { sumer }\end{array}$ & $\begin{array}{l}\text { Consumer } \\
\text { vs. } \\
\text { Industrials }\end{array}$ & $\begin{array}{l}\text { Industri- } \\
\quad \text { als } \\
\text { vs. Basic }\end{array}$ \\
\hline \multirow[t]{4}{*}{+3 to 0} & Mean & $0.53 \%$ & $0.62 \%$ & $2.55 \%$ & & & \\
\hline & Size & 32 & 61 & 62 & & & \\
\hline & SRT & $(1.65)^{*}$ & $(3.11)^{* * *}$ & $(17.99)^{* * *}$ & & & \\
\hline & t-test & & & & -0.09 & $(-1.80)^{*}$ & $(-2.01)^{* *}$ \\
\hline \multirow[t]{4}{*}{+2 to 0} & Mean & $0.78 \%$ & $0.79 \%$ & $2.51 \%$ & & & \\
\hline & Size & 32 & 61 & 62 & & & \\
\hline & SRT & $(3.68)^{* * *}$ & $(4.71)^{* * *}$ & $(17.04)^{* * *}$ & & & \\
\hline & t-test & & & & -0.01 & $(-1.66)^{*}$ & $(-2.24)^{* *}$ \\
\hline \multirow[t]{4}{*}{+1 to 0} & Mean & $0.51 \%$ & $1.06 \%$ & $1.46 \%$ & & & \\
\hline & Size & 32 & 61 & 62 & & & \\
\hline & SRT & $(2.57)^{* * *}$ & $(6.46)^{* * *}$ & $(9.32)^{* * *}$ & & & \\
\hline & t-test & & & & -0.76 & -1.16 & -0.60 \\
\hline \multirow[t]{4}{*}{-1 to 0} & Mean & $-0.46 \%$ & $-0.06 \%$ & $1.08 \%$ & & & \\
\hline & Size & 32 & 61 & 62 & & & \\
\hline & SRT & $(-2.93)^{* * *}$ & -1.29 & $(7.47)^{* * *}$ & & & \\
\hline & t-test & & & & -0.56 & $(-1.94)^{*}$ & $(-1.71)^{*}$ \\
\hline \multirow[t]{4}{*}{-2 to 0} & Mean & $-0.32 \%$ & $0.03 \%$ & $0.83 \%$ & & & \\
\hline & Size & 32 & 61 & 62 & & & \\
\hline & SRT & $(-2.05)^{* *}$ & -0.84 & $(6.30)^{* * *}$ & & & \\
\hline & t-test & & & & -0.42 & -1.24 & -0.96 \\
\hline \multirow[t]{4}{*}{-3 to 0} & Mean & $-0.45 \%$ & $0.18 \%$ & $0.50 \%$ & & & \\
\hline & Size & 32 & 61 & 62 & & & \\
\hline & SRT & $(-2.68)^{* *}$ & 0.19 & $(3.63)^{* * *}$ & & & \\
\hline & t-test & & & & -0.71 & -1.00 & -0.71 \\
\hline
\end{tabular}

Notes: $* * *, * *$, and $*$ denote significance of $1 \%, 5 \%$, and $10 \%$ respectively; SRT is standardized residual test.

Apparently, market reacts positively and increasing through 3 days prior to the anstrongly to the cash announcements of In- nouncement and 3 days after the announcedustrials stocks. CARs of those stocks kept 
ment. All t-statistics demonstrate the significance of those CARs at $1 \%$ level, whereas both Basic Material stocks and Consumer Good stocks exhibit the pattern of increasing trend from negative to positive abnormal cumulative returns from -3 days to +3 days.

The t-statistics also imply that there are no differences between CARs of Basic Material stocks and Consumer Goods stocks. Nevertheless, there are differences between CARs of Industrials stocks and both Consumer Goods stocks and Basic Materials stocks. The effects of cash dividends are stronger for Industrials stocks than those of the other two industries; especially for the event windows: day +3 to day 0 , day +2 to day 0 , and day -1 to day 0 . The differences might be partly explained by the fact that Industrials stocks offer a much higher yield (12.81\%) than Consumer Goods (8.57\%) and Basic Materials stocks (7.35\%).This must be related to the dividend policy which is influenced largely by industry types and other characteristics of the firm (Baker \& Powell, 2000). Further discussion on this topic is proposed on our next research steps.

\subsection{Stock price reaction to the change in the dividend}

In this section we examine the stock price reaction with regard to different types of div- idend changes, namely dividend increase announcements and dividend decrease announcements. Due to data unavailability of some dividend announcements of studied firms in 2010, our sample reduces from 198 cash dividend announcements to 160 dividend change announcements: 86 and 74 increase $^{1}$ and decrease announcements respectively.

In general, the stock market in Vietnam reacts positively to both dividend increase and dividend decrease announcements (see Table 5). CARs of both dividend increasing and dividend decreasing events show increasing trends. On the day of announcement, dividend increase announcements record CARs of $0.17 \%$, albeit not statistically significant at 5\% level. Dividend decrease announcements record CARs of $0.58 \%$ on the announcement date, being statistically significant at $1 \%$ level. All the CARs are statistically significant in the periods -3 to +10 , which suggests that the market reacts in a longer period around the announcement dates of dividend decreasing events. We also find evidence that the Vietnam's stock market responds stronger to dividend decreasing events than dividend increasing ones for the three-day window (i.e. day 0 to day +3 ).

\footnotetext{
${ }^{1}$ Dividend increase is defined as if dividend yield of the period is higher than that of previous period.
} 


\section{Table 5}

\begin{tabular}{|c|c|c|c|c|}
\hline \multirow[t]{2}{*}{ Windows } & \multicolumn{2}{|c|}{$\begin{array}{l}\text { Dividend increase } \\
\qquad(\mathrm{N}=86)\end{array}$} & \multicolumn{2}{|c|}{ Dividend decrease $(\mathrm{N}=74)$} \\
\hline & CARs & SRT & CARs & SRT \\
\hline-10 & $-1.36 \%$ & $-11.23 * * *$ & $-0.56 \%$ & $-3.57 * * *$ \\
\hline-9 & $-1.24 \%$ & $-10.05^{* * *}$ & $-0.48 \%$ & $-3.13 * * *$ \\
\hline-8 & $-0.91 \%$ & $-7.93 * * *$ & $-0.21 \%$ & -0.61 \\
\hline-7 & $-0.47 \%$ & $-3.99 * * *$ & $0.09 \%$ & 1.26 \\
\hline-6 & $-0.48 \%$ & $-4.19 * * *$ & $0.34 \%$ & $3.31 * * *$ \\
\hline-5 & $-0.95 \%$ & $-7.84 * * *$ & $0.25 \%$ & $2.20 * *$ \\
\hline-4 & $-0.28 \%$ & $-1.97 * *$ & $-0.13 \%$ & -0.79 \\
\hline-3 & $-0.11 \%$ & -0.92 & $0.45 \%$ & $2.85 * *$ \\
\hline-2 & $0.25 \%$ & $2.47 * *$ & $0.36 \%$ & $1.72 *$ \\
\hline-1 & $0.31 \%$ & $2.57 * *$ & $0.57 \%$ & $3.20 * * *$ \\
\hline 0 & $0.17 \%$ & 1.05 & $0.58 \%$ & $3.64 * * *$ \\
\hline 1 & $0.66 \%$ & $5.30 * * *$ & $1.56 \%$ & $10.16 * * *$ \\
\hline 2 & $0.79 \%$ & $6.93 * * *$ & $1.98 \%$ & $13.22 * * *$ \\
\hline 3 & $0.65 \%$ & $5.42 * * *$ & $2.38 \%$ & $16.28 * * *$ \\
\hline 4 & $0.49 \%$ & $4.38 * * *$ & $1.81 \%$ & $12.64 * * *$ \\
\hline 5 & $0.53 \%$ & $5.08 * * *$ & $1.74 \%$ & $12.51 * * *$ \\
\hline 6 & $0.36 \%$ & $3.86 * * *$ & $2.11 \%$ & $15.58 * * *$ \\
\hline 7 & $-0.38 \%$ & $-1.88 *$ & $2.29 \%$ & $17.30 * * *$ \\
\hline 8 & $-1.43 \%$ & $-10.13 * * *$ & $1.80 \%$ & $14.07 * * *$ \\
\hline 9 & $-2.51 \%$ & $-18.12 * * *$ & $1.18 \%$ & $10.74 * * *$ \\
\hline 10 & $-2.77 \%$ & $-20.63 * * *$ & $0.74 \%$ & $7.32 * * *$ \\
\hline
\end{tabular}

CARs of dividend increase vs. dividend decrease announcements

Note: $* * *, * *$, and $*$ denote significance of $1 \%, 5 \%$, and $10 \%$ respectively. 
Prior literature has been the source of well-documented evidence of positive price reactions to dividend increasing events, such as David et al. (1994) and Dasilas and Leventis (2011). This study's results are consistent with their findings and support the general signalling hypothesis. However, ours show that dividend decrease announcements have brought on positive price reactions, which is against the general signalling hypothesis. Other investigations using Indian data (Dharmarathne, 2013) and the UK data (Vieira \& Raposo, 2007) documented the similar findings that dividend decreasing events carry positive and significant CARs.

\subsection{Regression results}

As cash dividend announcements have significantly positive effects on the stock price on announcement dates, this might relate to the size of the dividends paid. We find the evidence that there is a positive correlation between abnormal stock returns and dividend yields. The result is shown in Table 6. This is different from the findings documented by Black and Scholes (1974) since they find no significant differences between CARs associated with high-yield and lowyield dividend stocks. The coefficient of the dividend yield is significant and positive in all estimates even after the inclusion of firm's specific risk (measured by the standard deviation of estimate in the market model). Intercept coefficients become significant after the inclusion of risk factor. The results, therefore, confirm the yield effect, i.e. the magnitude of dividend which affects the share price (after controlling for other risk factors). The results also reinforce the evidence that the effect of cash dividend is different among industries.

\section{Table 6}

Regression results

\begin{tabular}{lccccccc}
\hline Estimate & INTC & Yield & Amount & Stdev & Industrials & F-Statistics & Adj.R2 \\
\hline 1 & -0.002 & 0.055 & & & & 9.439 & 0.0411 \\
& $(-0.84)$ & $(3.48)^{* * *}$ & & & $(0.02)^{* *}$ & \\
2 & -0.003 & & $5.43 \mathrm{E}-06$ & & 5.391 & 0.0218 \\
& $(-0.88)$ & & $(2.32)^{* *}$ & & & $(0.02)^{* *}$ & \\
3 & -0.004 & 0.048 & & & 0.008 & 7.095 & 0.0583 \\
& $(-1.45)$ & $(2.68)^{* * *}$ & & & $(2.14)^{* *}$ & $(0.00)^{* * *}$ & \\
4 & -0.034 & 0.063 & & 2.671 & & 8.828 & 0.0736 \\
& $(-$ & $(3.53)^{* * *}$ & & $(2.81)^{* * *}$ & & $(0.00)^{* * *}$ & \\
& $2.92)^{* * *}$ & & & & & \\
& -0.033 & 0.056 & & 2.492 & 0.007 & 7.173 & 0.0859 \\
& $(-$ & $(3.14)^{* * *}$ & & $(2.63)^{* * *}$ & $(1.90)^{* *}$ & $(0.00)^{* * *}$ & \\
& $2.89)^{* * *}$ & & & & & \\
\hline
\end{tabular}


Notes: This panel shows all five model specifications of abnormal returns (dependent variable is average abnormal returns of stocks on announcement dates). The numbers in the brackets represent standard deviations of coefficients and p-value of f-statistics. Amount is absolute value of cash dividends. Yield is calculated on amount of dividends over stock price one day prior to the announcement date. Stdev is a control variable, which is used as a proxy for firm's specific risk in a portfolio. Industrials is a dummy variable that has value of 1 if firm is in the Industrials industry, and 0 otherwise.

$* * *, * *$, and $*$ denote significance of $1 \%, 5 \%$, and $10 \%$ respectively.

\section{Conclusion}

This study aims at finding out the relationship between cash dividend announcements and share prices, using the data of Vietnamese listed stocks on HOSE in 2011. The results show stock prices react significantly and positively to the announcements of cash dividends, including both dividend increasing and dividend decreasing events. Moreover, Industrials stocks exhibit strongly and significantly positive cumulative abnormal returns. These abnormal returns are associated with dividend yield. This result is different from the findings in Black and Scholes (1974) that there exist no significant differences between CARs associated with high yield dividend stocks and low yield dividend stocks. Furthermore, the results of this study support the relevance dividend hypothesis and signaling hypothesis.

Our future research on this topic will cover a longer period of time to capture changes in how market reacts to the cash dividend announcements, specifically to the dividend initiation, dividend increase events, and dividend decrease events. In addition, we will examine the impact of firms' characteristics on the way market reacts to the cash announcement, i.e. firm size effect. Finally, the efficient market hypothesis will also be examined and discussed in the further study

\section{References}

Al-Malkawi, H.-A., Rafferty, M., \& Pillai, R. (2010). Dividend policy: A review of theories and empirical evidence. EuroJournals, 9, 172-200.

Ariff, M., \& Finn, F. J. (1986). Announcement effects and market efficiency in a thin market: An empirical application to the Singapore equity market. Asia Pacific Journal of Management, 6, 243-267.

Asquith, P., \& Mullins, D. (1986). The impact of initiating dividend payments on shareholders' wealth. The Journal of Business, 46, 77-96.

Baker, H. K., \& Powell, G. E. (2000). Determinants of corporate dividend policy: A survey of NYSE firms. Financial Practice and Education, 10, 29-40.

Bernstein, P. L. (1996). Dividends: The puzzle. Journal of Applied Corporate Finance, 9(1), 16-22.

Black, F., \& Scholes, M. S. (1974). The effects of dividend yield and dividend policy on common stock prices and returns. Journal of Financial Economics, 1(1), 1-22. 
Boyd, J. H., \& Jagannathan, R. (1994). Ex-Dividend price behavior of common stocks. Report 173. Federal Reserve Bank of Minneapolis.

Brown, S. J., \& Warner, J. B. (1985). Using daily stock returns. Journal of Financial Economics, 14(1), 3-31.

Dasilas, A., \& Leventis, S. (2011), Stock market reaction to dividend announcements: Evidence from the Greek stock market. International Review of Economics \& Finance, 20(2), 302-311.

David, J., Denis, D. K., \& Sarin, A. (1994). The information content of dividend changes: Cash flow signaling, overinvestment, and dividend clienteles. Journal of Financial and Quantitative Analysis, 29, 567-587. doi:10.2307/2331110.

Dharmarathne, D. G. (2013). Stock price reaction to dividend announcements and information efficiency in Sri Lanka share. International Journal of Research in Social Sciences, 3(2), 100-111.

Eades, K., Hess, P., \& Kim, E. H. (1984). On interpreting security returns during the ex-dividend period. Journal of Financial Economics, 13, 3-35.

Easton, S. (1991). Earnings and dividends: Is there an interaction effect? Journal of Business, Finance and Accounting, 18(2), 255-266. doi: 10.1111/j.1468-5957.1991.tb00592.x

Gordon, M. J. (1963). Optimal investment and financing policy. The Journal of Finance, 18(2), 264272.

Gunasekarage, A., \& Power, D. (2006). Anomalous evidence in dividend announcement effect. Managerial Finance, 32, 209-226.

Gupta, S., Dogra, B., Vashisht, A. K., \& Ghai, S. (2012). Stock price reaction to dividend announcements. International Journal of Financial Management, 2(2), 23-31.

Harada, K., \& Nguyen, P. (2005). Dividend change context and signaling efficiency in Japan. Pacific/Basin Finance Journal, 13, 504-522.

Hashemijoo, M., Ardekani, M., \& Younesi, N. (2012). The impact of dividend policy on share price volatility in the Malaysian stock market. Journal of Business Studies Quarterly, 4(1), 111-129.

Hess, P. J. (1981). The dividend debate: 20 years of discussion. In J. Stern \& D. Chew (Eds.), The revolution in corporate finance. Cambridge, MA: Blackwell Publishers.

Krishnaswami, S., \& Subramaniam, V. (1999). Information asymmetry, valuation, and the corporate spin-off decision. Journal of Financial Economics, 53(1), 73-112.

Lakonishok, J, \& Vermaelen, T. (1986). Tax induced trading around ex-dividend days. Journal of Financial Economics, 3, 287-320.

Lee, S. P., Isa, M., \& Lim, W. L. (2012). Dividend changes and future profitability: Evidence from Malaysia, Asian Academy of Management Journal of Accounting and Finance Malaysia, 8(2), 93-110.

Lintner, J. (1962). Dividends, earnings, leverage, stock prices and supply of capital to corporations. The Review of Economics and Statistics, 64, 243-269.

Lonie, A. A., Abeyratna, G., Power, D. M., \& Sinclair, C. D. (1996). The stock market reaction to dividend announcements: A UK study of complex market signals. Journal of Economic Studies, 23(1), 32-52. 
MacKinlay, A. C. (1997). Event studies in economics and finance. Journal of Economic Literature, 35(1), 13-39.

McCluskey, T., Burton, B. M., Power, D. M., \& Sinclair, C. D. (2006). Evidence on the Irish stock market's reaction to dividend announcements, Applied Financial Economics, 16(8), 617-628.

Miller, M. H., \& Modigliani, F. (1961). Dividend policy, growth, and the valuation of shares. The Journal of Business, 34(4), 411-433.

Miller, M. H., \& Rock, K. (1985). Dividend policy under asymmetric information. The Journal of Finance, 40(4), 1031-1051. doi: 10.1111/j.1540-6261.1985.tb02362.x

Miller, M. H., \& Scholes, M. S. (1978). Dividends and taxes. Journal of Financial Economics 6, $333-$ 264.

Nissim, D., \& Ziv, A. (2001). Dividend changes and future profitability. The Journal of Finance, 56(6), 2111-2133.

Suwanna, T. (2012). Impact of dividend announcement on stock return. Procedia - Social and Behavioural Sciences, 40, 721-725.

Urooj, S. F., \& Zafar, N. (2008). Share price reaction to dividend announcements. Business Review, Cambridge, 10(1), 322-329.

Vieira, E. S., \& Raposo, C. C. (2007). Signalling with dividends? The signalling effects of dividend change announcements: New evidence from Europe. Retrieved from SSRN: http://ssrn.com/abstract $=955768$ or http://dx.doi.org/10.2139/ssrn.955768

Walter, J. E. (1963). Dividend policy: Its influence on the value of the enterprise. The Journal of Finance, 18, 280-291. 